Check for updates

Cite this: J. Mater. Chem. A, 2021, 9, 26401

Received 21st September 2021 Accepted 9th November 2021

DOI: $10.1039 / d 1 t a 08115 b$

rsc.li/materials-a

\section{Catalytic mechanism of spinel oxides for oxidative electrolyte decomposition in $\mathrm{Mg}$ rechargeable batteries $\uparrow$}

\author{
Jonghyun Han, (D) a Shunsuke Yagi, (D) *a Hirokazu Takeuchi, ${ }^{\text {b }}$ \\ Masanobu Nakayama iD bc and Tetsu Ichitsubo iD d
}

One of the primary drawbacks in the development of $\mathrm{Mg}$ rechargeable batteries is their low operating voltage. Although electrolytes with a wide potential window have been used for high-voltage $\mathrm{Mg}$ rechargeable batteries, these electrolytes undergo oxidative decomposition at the surface of the positive electrode active materials at relatively low potentials. Moreover, the overpotential and kinetics of oxidative electrolyte decomposition significantly depend on the transition metal ion in spinel oxides (e.g., $\mathrm{MgMn}_{2} \mathrm{O}_{4}, \mathrm{MgFe}_{2} \mathrm{O}_{4}$, or $\mathrm{MgCO}_{2} \mathrm{O}_{4}$ ) used as positive electrode active materials. Because the catalytic activities of spinel oxides for electrolyte decomposition are different, electrolyte decomposition can be effectively suppressed by using transition metal ions with high overpotential for electrolyte decomposition in target spinel oxides. However, the mechanism of the catalytic reaction has not yet been elucidated. Herein, we determined that the direct electron transfer from the electrolyte to the electrode was slow, whereas the electron transfer via the oxidation reaction of spinel oxides was fast. Furthermore, we used experimental data and calculations to demonstrate that the catalytic activity for oxidative electrolyte decomposition was correlated with the valence band maximum (VBM) of spinel oxides; that is, low VBMs were correlated with high overpotentials for oxidative electrolyte decomposition.

\section{Introduction}

Recently, the demand for rechargeable batteries with high energy density has increased because the markets for longrange electric vehicles and high-performance mobile devices have expanded. Li-ion batteries (LIBs) are currently used in a wide range of applications because of their remarkable energy density and cyclability. Owing to the low standard electrode potential $(-3.04 \mathrm{~V}$ vs. SHE) and high theoretical specific capacity (2062 $\mathrm{mA} \mathrm{h} \mathrm{cm}{ }^{-3}$ or $3861 \mathrm{~mA} \mathrm{~h} \mathrm{~g}^{-1}$ ) of Li metal, rechargeable batteries with a Li metal negative electrode should exhibit high energy density. However, Li metal forms dendrites, which are needle-like structures, on the negative electrode surface during charging, causing the capacity to decrease, short circuits, and even fires. Hence, graphite, with a relatively low specific capacity $\left(372 \mathrm{~mA} \mathrm{~h} \mathrm{~g}^{-1}\right)$, has been used as a LIB negative

${ }^{a}$ Institute of Industrial Science, The University of Tokyo, 4-6-1 Komaba, Meguro-ku, Tokyo 153-8505, Japan. E-mail: syagi@iis.u-tokyo.ac.jp

${ }^{b}$ Department of Advanced Ceramics, Nagoya Institute of Technology, Gokiso, Showa, Nagoya, Aichi 466-8555, Japan

'Department of Frontier Materials, Nagoya Institute of Technology, Gokiso, Showa, Nagoya, Aichi 466-8555, Japan

${ }^{d}$ Institute for Materials Research, Tohoku University, 2-1-1 Katahira, Aoba-ku, Sendai 980-8577, Japan

$\dagger$ Electronic supplementary information (ESI) available. See DOI: $10.1039 / \mathrm{d} 1 \mathrm{ta} 08115 \mathrm{~b}$ electrode. Conversely, the tendency of $\mathrm{Mg}$ metal to form dendrites is lower than that of Li. Furthermore, $\mathrm{Mg}$ presents the lowest standard electrode potential $(-2.37 \mathrm{~V} v s$. SHE) among all the metals that can be safely handled in air, and its theoretical specific capacity can reach $3833 \mathrm{~mA} \mathrm{~h} \mathrm{~cm}{ }^{-3}$ or $2205 \mathrm{~mA} \mathrm{~h} \mathrm{~g}^{-1} \cdot{ }^{1-4}$ Therefore, $\mathrm{Mg}$ rechargeable batteries (MRBs) featuring a $\mathrm{Mg}$ metal negative electrode are considered some of the most promising and safe next-generation batteries with high energy density. ${ }^{5,6}$

Many studies on MRBs have been conducted since 2000 when Aurbach et al. fabricated a prototype MRB featuring $\mathrm{Mg}$ metal as the negative electrode, Chevrel-phase $\mathrm{Mo}_{6} \mathrm{~S}_{8}$ as the positive electrode, and $\mathrm{Mg}$ organohaloaluminate salts $\left(\mathrm{Mg}\left(\mathrm{AlCl}_{2} \mathrm{BuEt}\right)_{2}\right)$ synthesized via the complexation of $\mathrm{MgBu}_{2}$, a Lewis base, and $\mathrm{AlCl}_{2} \mathrm{Et}$, a Lewis acid, $(\mathrm{Bu}=$ butyl, $\mathrm{Et}=$ ethyl $)$ in tetrahydrofuran (THF), as the electrolyte. ${ }^{7}$ Even though $\mathrm{Mo}_{6} \mathrm{~S}_{8}$ can be used at room temperature because of the high mobility of $\mathrm{Mg}^{2+}$ ions in its structure and exhibits excellent cyclability, the redox potential in the prototype MRB was low $(1.0-1.2 \mathrm{~V} v s$. $\left.\mathrm{Mg} / \mathrm{Mg}^{2+}\right)$ and its capacity $\left(\sim 75 \mathrm{~mA} \mathrm{~h} \mathrm{~g}{ }^{-1}\right)$ was significantly lower than the theoretical capacity $\left(122 \mathrm{~mA} \mathrm{~h} \mathrm{~g}^{-1}\right)$. Therefore, other compounds with higher redox potentials and capacities than $\mathrm{Mo}_{6} \mathrm{~S}_{8}$ have been considered as positive electrode active materials (Fig. 1). ${ }^{7-16}$ Typically, the redox potentials and capacities of oxides are higher than those of sulfides. We revealed that $\mathrm{MgM}_{2} \mathrm{O}_{4}(\mathrm{M}=\mathrm{Cr}, \mathrm{Mn}, \mathrm{Fe}, \mathrm{Co})$ and $\mathrm{Co}_{3} \mathrm{O}_{4}$ with an oxide based 


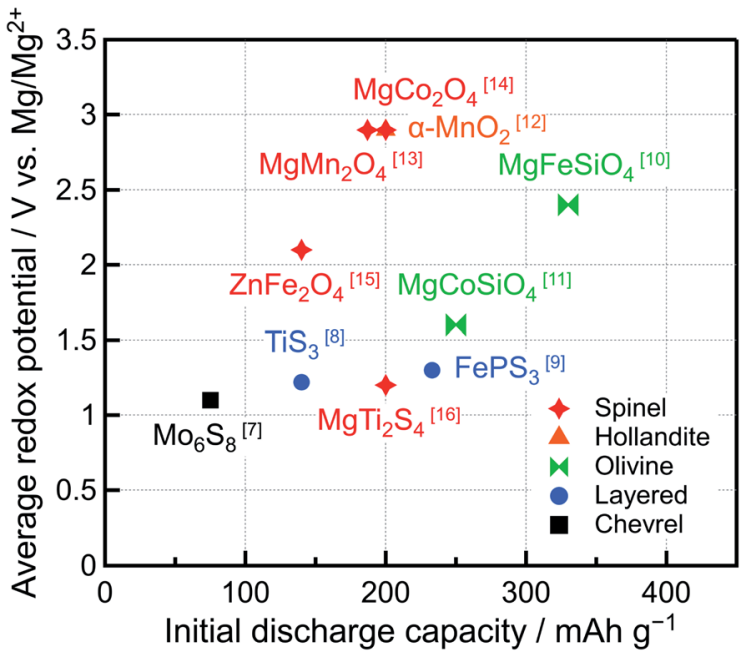

Fig. 1 Average redox potentials and initial discharge capacities of reported positive electrode active materials for $\mathrm{Mg}$ rechargeable batteries.

spinel-type structure allow the insertion of $\mathrm{Mg}^{2+}$ ions at high potentials $\left(\sim 2-3 \mathrm{~V} v s . \mathrm{Mg} / \mathrm{Mg}^{2+}\right)$ and exhibit large theoretical capacities (220-270 $\left.\mathrm{mA} \mathrm{h} \mathrm{g}^{-1}\right){ }^{14}$ Especially, the redox potential of $\mathrm{MgCo}_{2} \mathrm{O}_{4}$ was high $\sim 2.9 \mathrm{~V} v$ s. $\mathrm{Mg} / \mathrm{Mg}^{2+}$, and its capacity was $200 \mathrm{~mA} \mathrm{~h} \mathrm{~g}^{-1}$ (theoretical capacity: $260 \mathrm{~mA} \mathrm{~h} \mathrm{~g}^{-1}$ ). However, the system was maintained at $150{ }^{\circ} \mathrm{C}$ because the $\mathrm{Mg}^{2+}$ ion mobility of oxides is lower than that of sulfides, hindering roomtemperature operation. ${ }^{17-19}$ In addition, several spinel oxides with controlled structures and/or compositions, such as $\mathrm{MgMn}_{2} \mathrm{O}_{4} / \mathrm{V},{ }^{20} \quad \mathrm{ZnMnO}_{3},{ }^{21} \quad \mathrm{Mg}_{4} \mathrm{~V}_{5-x} \mathrm{Ni}_{x} \mathrm{O}_{12},{ }^{22} \quad$ and $\mathrm{Mg}_{1+y} \mathrm{Co}_{2-x-y} \mathrm{Mn}_{x} \mathrm{O}_{4}{ }^{23}$ have been studied as positive electrode active materials for MRBs, but their evaluations were conducted at high temperatures $\left(>90{ }^{\circ} \mathrm{C}\right)$ to enhance the mobility of $\mathrm{Mg}^{2+}$ ions. Moreover, despite their high redox potentials and theoretical capacities, MRBs featuring spinel oxides as positive electrode active materials typically suffer from being sufficiently charged because of the lack of suitable electrolytes with high anodic stability at potentials of up to $\sim 4 \mathrm{~V} v s$. $\mathrm{Mg} / \mathrm{Mg}^{2+}$, leading to lower specific capacity and inferior cyclability.

Table 1 lists MRB electrolytes with anodic stability at potentials higher than $2 \mathrm{~V}$ vs. $\mathrm{Mg} / \mathrm{Mg}^{2+}$. $\mathrm{Cl}^{-}$-ion-containing electrolytes generally show a high coulombic efficiency (90$100 \%$ ) of $\mathrm{Mg}$ deposition and dissolution. For example, $0.25 \mathrm{M}$ $\mathrm{Mg}\left(\mathrm{AlCl}_{2} \mathrm{BuEt}\right)_{2}$ in THF was reported to have $\sim 100 \%$ coulombic efficiency. However, the anodic stability was low $(2.2 \mathrm{~V} v s . \mathrm{Mg} /$ $\left.\mathrm{Mg}^{2+}\right)$. Although many $\mathrm{Cl}^{-}$-ion-containing electrolytes have been investigated, the anodic stability is not still sufficient. Furthermore, the corrosivity of $\mathrm{Cl}^{-}$-ion-containing electrolytes prevents the use of conventional and inexpensive current collectors and cell cases (e.g., $\mathrm{Al}, \mathrm{Ni}, \mathrm{Cu}$, and stainless steel) used for LIBs. Hence, expensive Pt with high corrosion resistance was used as a current collector in many studies. ${ }^{24}$ Therefore, we focused on a bis(trifluoromethanesulfonyl)amide (TFSA)-based electrolyte, which is a $\mathrm{Cl}^{-}$-ion-free electrolyte. ${ }^{25} \mathrm{It}$ was reported that this electrolyte inhibited electrode corrosion and its anodic stability was higher than $4.1 \mathrm{~V} v s . \mathrm{Mg} / \mathrm{Mg}^{2+}$ on an $\mathrm{Al}$ current collector; however, its coulombic efficiency was low $(<60 \%)$ owing to the passivation of the Mg negative electrode in the presence of $\mathrm{TFSA}^{-}$ions. Passivation prevented $\mathrm{Mg}$ deposition/dissolution at room temperature and increased the overpotential for the $\mathrm{Mg}$ dissolution reaction during discharging. ${ }^{26-28}$ Although the anodic stability was reported to be higher than $4.1 \mathrm{~V}$ vs. $\mathrm{Mg} / \mathrm{Mg}^{2+}$ on an $\mathrm{Al}$ current collector, the TFSAbased electrolyte was oxidatively decomposed at a potential over $3 \mathrm{~V}$ vs. $\mathrm{Mg} / \mathrm{Mg}^{2+}$ when spinel oxides were used as positive electrode active materials. ${ }^{29}$ Therefore, the actual thermodynamic oxidation potential of this electrolyte is about $3 \mathrm{Vvs.} \mathrm{Mg/}$ $\mathrm{Mg}^{2+}$ or less, and the reported high anodic limit of $>4.1 \mathrm{~V} v s . \mathrm{Mg} /$ $\mathrm{Mg}^{2+}$ was attributed to the high overpotential and sluggish kinetics of oxidative electrolyte decomposition on the Al current collector. In other words, spinel oxides have catalytic activities for anodic electrolyte decomposition. We have previously reported that oxidative electrolyte decomposition can be significantly suppressed by increasing the $\mathrm{Fe}$ ion content of $\mathrm{Mg}\left(\mathrm{Mn}_{1-x} \mathrm{Fe}_{x}\right)_{2} \mathrm{O}_{4}$ spinel oxides because $\mathrm{Fe}$ ions are less catalytically active than $\mathrm{Mn}$ ions. ${ }^{29}$ Changing the transition metal ion content of spinel oxides is a new method for improving the performance of positive electrode active materials of MRBs featuring conventional electrolytes.

To the best of our knowledge, to date, no reports have been published on the effect of the transition metal ions of spinel oxides on the catalytic activity of spinel oxides for oxidative electrolyte decomposition. Therefore, in this study, we

Table 1 Properties of non-aqueous electrolytes for $\mathrm{Mg}$ rechargeable batteries reported in the literature. The metals in parentheses indicate the current collectors ${ }^{a}$

\begin{tabular}{|c|c|c|c|c|}
\hline Type & Non-aqueous electrolytes & $E_{\mathrm{OX}} / \mathrm{V} v s . \mathrm{Mg} / \mathrm{Mg}^{2+}$ & Coulombic efficiency/\% & Ref. \\
\hline \multirow[t]{4}{*}{ Halide-based } & $0.25 \mathrm{M} \mathrm{Mg}\left(\mathrm{AlCl}_{2} \mathrm{BuEt}\right)_{2}$ in THF & $2.2(\mathrm{Pt})$ & $\sim 100$ & 7,30 and 31 \\
\hline & $0.4 \mathrm{M}(\mathrm{PhMgCl})_{2}-\mathrm{AlCl}_{3}$ in THF & $<3(\mathrm{Pt})$ & 100 & 32 \\
\hline & $0.5 \mathrm{M}(\mathrm{PhMgCl})_{2}-\mathrm{Mes}_{3} \mathrm{~B}$ in THF & $3.5(\mathrm{Pt})$ & 100 & 34 \\
\hline & $0.25 \mathrm{M}\left(\mathrm{MgCl}_{2}\right)_{2}-\mathrm{AlCl}_{3}$ in DME & $3.1(\mathrm{Pt})$ & $>99$ & 35 \\
\hline Non-halide-based & $0.75 \mathrm{M} \mathrm{Mg}\left(\mathrm{CB}_{11} \mathrm{H}_{12}\right)_{2}$ in $\mathrm{G} 4$ & $3.8(\mathrm{Al})$ & $>99$ & 36 and 37 \\
\hline
\end{tabular}

${ }^{a} E_{\mathrm{Ox}}$ : oxidation potential; Bu: butyl; Et: ethyl; Ph: phenyl; HMDS: hexamethyldisilazane; Mes ${ }_{3} \mathrm{~B}$ : tri(3,5-dimethylphenyl)borane; THF: tetrahydrofuran; DME: dimethoxyethane; G4: tetraethylene glycol dimethyl ether; Pyr1,3: $N$-methyl- $N$-propylpyrrolidinium. 
evaluated the catalytic mechanism using experimental and theoretical methods and demonstrated that oxidative electrolyte decomposition correlated with the location of the valence band maxima (VBMs) of spinel oxides and that of the highest occupied molecular orbital (HOMO) of the electrolyte.

\section{Results and discussion}

\section{Oxidative decomposition behavior of the electrolyte}

The electrochemical properties of a TFSA-based electrolyte were evaluated. The cyclic voltammogram of a cell featuring a Pt plate as the working electrode (WE), a $\mathrm{Mg}$ ribbon as the counter electrode (CE), $\mathrm{Ag} / \mathrm{Ag}^{+}$as the reference electrode (RE), and a $0.5 \mathrm{M}[\mathrm{Mg}(\mathrm{G} 4)][\mathrm{TFSA}]_{2} /[\mathrm{Pyr} 1,3][$ TFSA $]$ solution as the electrolyte was obtained at $100{ }^{\circ} \mathrm{C}$ and a scan rate of $10 \mathrm{mV} \mathrm{s}^{-1}$ in the potential range of -3.6 to $1.4 \mathrm{~V}$ vs. $\mathrm{Ag} / \mathrm{Ag}^{+}$(Fig. 2a). The deposition/dissolution of $\mathrm{Mg}$ in the electrolyte was observed at $\sim-2.6 \mathrm{~V} v s . \mathrm{Ag} / \mathrm{Ag}^{+}$. Subsequently, the measured potentials $v s$. $\mathrm{Ag} / \mathrm{Ag}^{+}$were converted into values vs. $\mathrm{Mg} / \mathrm{Mg}^{2+}$ using the following equation: $0 \mathrm{~V}$ vs. $\mathrm{Mg} / \mathrm{Mg}^{2+}=-2.6 \mathrm{~V}$ vs. $\mathrm{Ag} / \mathrm{Ag}^{+}$, as previously described in the literature. ${ }^{25}$ The cyclic voltammograms of a cell featuring a blank electrode, which consisted of a mixture of Super P (SP) as the conductive agent, and polyvinylidene difluoride (PVdF) as the binder (SP : PVdF mass ratio of $9: 1$ ), on a Pt plate as the current collector were obtained to evaluate the anodic stability of the electrolyte in the potential range of 1-4 $\mathrm{V}$ vs. $\mathrm{Mg} / \mathrm{Mg}^{2+}$ (Fig. 2b). The anodic current increased at potentials higher than $3.7 \mathrm{~V} v s . \mathrm{Mg} / \mathrm{Mg}^{2+}$ on the Pt plate, which was attributed to oxidative electrolyte decomposition. ${ }^{39,40}$ For comparison, the cyclic voltammetry (CV) of a cell featuring a blank electrode on an $\mathrm{Al}$ plate as the current collector was also measured in the wide potential range of 1-5 V vs. $\mathrm{Mg} / \mathrm{Mg}^{2+}$ (Fig. 2c). Our results revealed that the electrolyte was oxidatively decomposed at potentials higher than $3.8 \mathrm{~V} v s$. $\mathrm{Mg} / \mathrm{Mg}^{2+}$ when the Al plate was used as the current collector. The anodic current was negligible at potentials lower than $3.8 \mathrm{~V}$, indicating that the $\mathrm{Al}$ electrode did not dissolve even though the standard electrode potential of $\mathrm{Al}(-1.66 \mathrm{~V} v s$. SHE) was only $0.7 \mathrm{~V}$ higher than that of $\mathrm{Mg}$. In a preliminary experiment, we demonstrated that the TFSA-based electrolyte reinforces the passivation layer formed on the unpolished $\mathrm{Al}$ electrode (Fig. S1†), leading to the electrode stabilization over a wide potential range. In addition, $\mathrm{Al}$ anodic dissolution was observed at potentials higher than $2 \mathrm{~V} v s . \mathrm{Mg} / \mathrm{Mg}^{2+}$ when polishing the electrode surface, suggesting that the oxidized passivation layer originally formed on the $\mathrm{Al}$ is necessary for protecting the $\mathrm{Al}$ electrode. Therefore, in this study, an unpolished $\mathrm{Al}$ plate was used as the current collector owing to its low cost and high anodic stability.

The cyclic voltammograms of $\mathrm{MgM}_{2} \mathrm{O}_{4}(\mathrm{M}=\mathrm{Mn}, \mathrm{Fe}$, and Co $)$ spinel oxides on an $\mathrm{Al}$ plate as the positive electrode current collector measured in a $0.5 \mathrm{M}[\mathrm{Mg}(\mathrm{G} 4)][\mathrm{TFSA}]_{2} /[\mathrm{Pyr} 1,3][\mathrm{TFSA}]$ solution at $100{ }^{\circ} \mathrm{C}$ are presented in Fig. 3a-c. It has been reported that according to the reaction described by eqn (1), the insertion of $\mathrm{Mg}^{2+}$ ions into $\mathrm{MgM}_{2} \mathrm{O}_{4}$ proceeded via a two-phase reaction between the $\mathrm{MgM}_{2} \mathrm{O}_{4}$ spinel and $\mathrm{Mg}_{2} \mathrm{M}_{2} \mathrm{O}_{4}$ rocksalt phases during discharging, as follows: ${ }^{14}$

$$
\mathrm{MgM}_{2} \mathrm{O}_{4}+x\left(\mathrm{Mg}^{2+}+2 \mathrm{e}^{-}\right) \rightarrow(1-x) \mathrm{MgM}_{2} \mathrm{O}_{4}+x \mathrm{Mg}_{2} \mathrm{M}_{2} \mathrm{O}_{4}
$$

During charging, the reaction proceeds in the opposite direction. Hence, the cyclic voltammograms were obtained by scanning the potential in the cathodic direction from the opencircuit potential (OCP) in the range of $0.8-4 \mathrm{~V} v s . \mathrm{Mg} / \mathrm{Mg}^{2+}$ at a scan rate of $25 \mu \mathrm{V} \mathrm{s}^{-1}$. Two cathodic peaks are observed at 2.2 and $1.5 \mathrm{~V}$ vs. $\mathrm{Mg} / \mathrm{Mg}^{2+}$ in the cyclic voltammogram of $\mathrm{MgMn}_{2} \mathrm{O}_{4}$ (inset of Fig. 3a). As shown in SXRD patterns for $\mathrm{MgMn}_{2} \mathrm{O}_{4}$ in Fig. $\mathrm{S} 2 \mathrm{a}, \dagger$ there is no phase transformation to rocksalt after the polarization at $1.85 \mathrm{~V} v s . \mathrm{Mg} / \mathrm{Mg}^{2+}\left(\sim 46 \mathrm{~mA} \mathrm{~h}{ }^{-1}\right)$. Furthermore, only a small rocksalt peak was observed at around $13^{\circ}$ after the
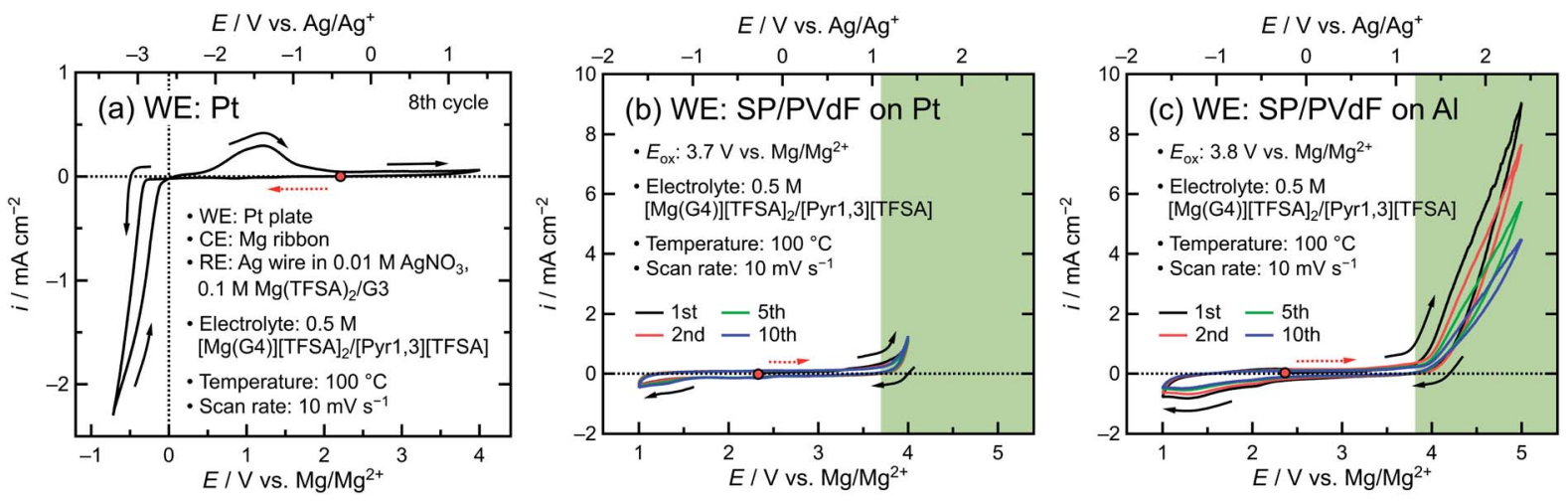

Fig. 2 Cyclic voltammograms of cells featuring a $0.5 \mathrm{M}[\mathrm{Mg}(\mathrm{G} 4)][T F S A]_{2} /[\mathrm{Pyr} 1,3][\mathrm{TFSA}]$ solution as the electrolyte at $100{ }^{\circ} \mathrm{C}$ and a scan rate of $10 \mathrm{mV} \mathrm{s}^{-1}$. The cells comprised (a) a Pt plate, (b) a blank electrode on a Pt current collector, and (c) a blank electrode on an Al current collector as the working electrodes (WEs); a Mg ribbon as the counter electrode (CE); and a Ag wire in a $0.01 \mathrm{M} \mathrm{AgNO} 3,0.1 \mathrm{M} \mathrm{Mg}(\mathrm{TFSA}){ }_{2} / \mathrm{G} 3 \mathrm{solution}$ as the reference electrode $(\mathrm{RE})$. The electrolyte was decomposed at potentials higher than the oxidation potential ( $\left.E_{\mathrm{ox}}\right)$, as indicated by the green areas in (b) and (c). The open circuit potentials and scan directions are illustrated using solid red circles and arrows, respectively. The dotted arrows indicate the initial potential scan direction. Here, G3, G4, TFSA, and Pyr1,3 denote triethyleneglycol dimethyl ether, tetraethylene glycol dimethyl ether, bis(trifluoromethanesulfonyl)amide, and $N$-methyl- $N$-propylpyrrolidinium, respectively. 

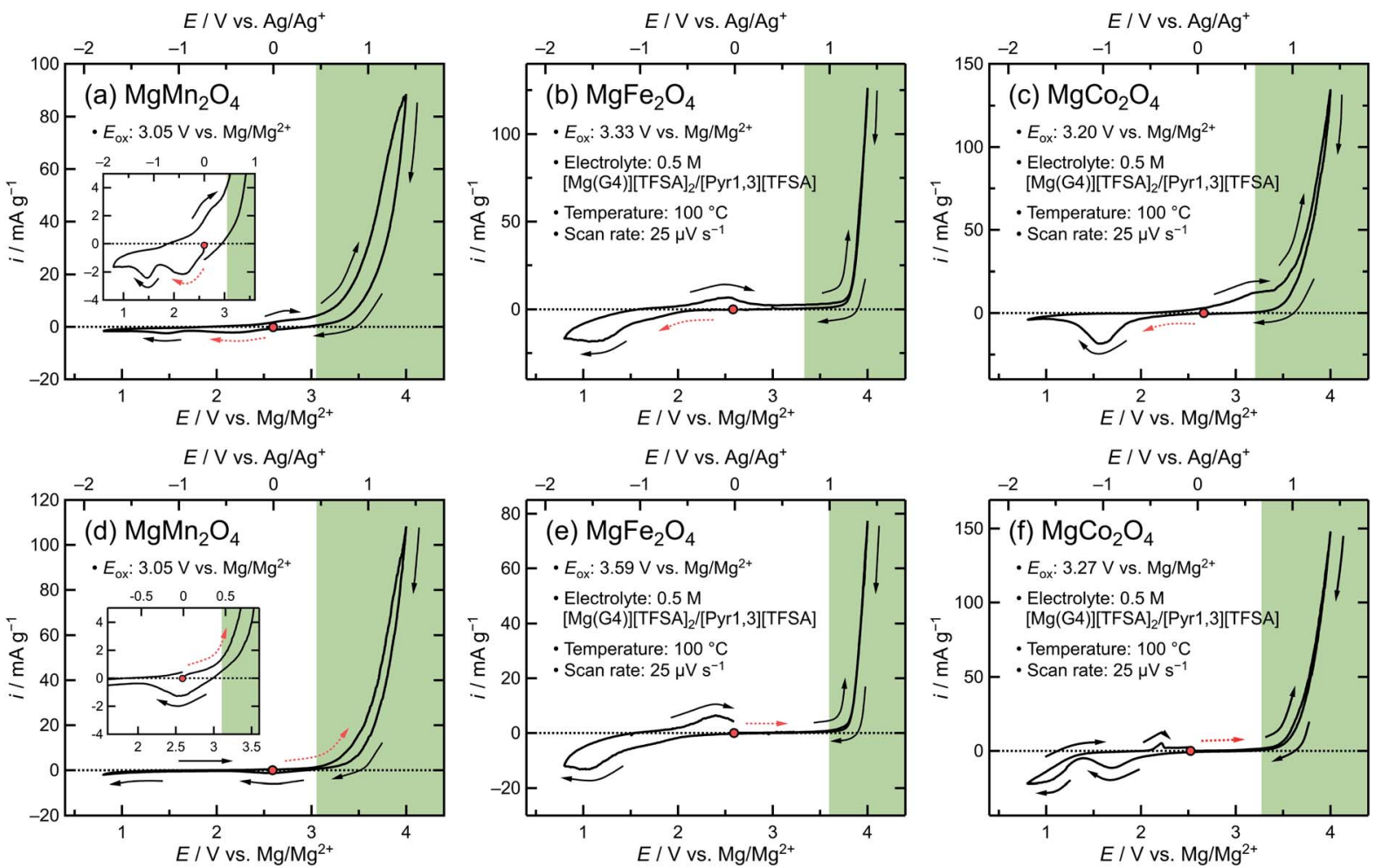

Fig. 3 Cyclic voltammograms of cells featuring (a) $\mathrm{MgMn}_{2} \mathrm{O}_{4}$, (b) $\mathrm{MgFe}_{2} \mathrm{O}_{4}$, and (c) $\mathrm{MgCO}_{2} \mathrm{O}_{4}$ as the working electrodes (WEs) in the cathodic direction and of cells featuring (d) $\mathrm{MgMn}_{2} \mathrm{O}_{4}$, (e) $\mathrm{MgFe}_{2} \mathrm{O}_{4}$, and (f) $\mathrm{MgCO}_{2} \mathrm{O}_{4}$ as the WEs in the anodic direction at $100{ }^{\circ} \mathrm{C}$ and a scan rate of $25 \mu \mathrm{V}$ $\mathrm{s}^{-1}$. The electrolyte, counter electrode and reference electrode of the cells consisted of a $0.5 \mathrm{M}[\mathrm{Mg}(\mathrm{G} 4)][T F S A]_{2} /[\mathrm{Pyr} 1,3][T F S A]$ solution, a Mg ribbon, and a $\mathrm{Ag}$ wire in $0.01 \mathrm{M} \mathrm{AgNO}_{3}, 0.1 \mathrm{M} \mathrm{Mg}(\mathrm{TFSA})_{2} / \mathrm{G} 3$. The electrolyte decomposed above the oxidation potential ( $\left.E_{\mathrm{Ox}}\right)$, as indicated by the green rectangles. The open circuit potentials and scan directions are illustrated using the solid red circles and arrows, respectively; in particular, the dotted arrows indicate the initial potential scan direction. Here, G3, G4, TFSA, and Pyr1,3 denote triethyleneglycol dimethyl ether, tetraethylene glycol dimethyl ether, bis(trifluoromethanesulfonyl)amide, and $N$-methyl- $N$-propylpyrrolidinium, respectively.

polarization at $0.8 \mathrm{~V}$ vs. $\mathrm{Mg} / \mathrm{Mg}^{2+}$ until the electric amount reached $\sim 188 \mathrm{~mA} \mathrm{~h} \mathrm{~g}^{-1}$ (theoretical capacity: $270 \mathrm{~mA} \mathrm{~h} \mathrm{~g}^{-1}$ ). These results suggest that the $\mathrm{Mg}^{2+}$ ions were inserted into $\mathrm{MgMn}_{2} \mathrm{O}_{4}$ mainly without the phase transition. It should be noted that $\mathrm{MgCo}_{2} \mathrm{O}_{4}$ showed the obvious phase transformation to rocksalt in Fig. S2c $\dagger$ as previously reported. In addition, there is a possibility of reductive electrolyte decomposition. Further study is required to clarify the emergence of the two peaks. An anodic peak, which was ascribed to the oxidation reaction of $\mathrm{Mn}$ ions, emerged at $\sim 2.75 \mathrm{~V} v s . \mathrm{Mg} / \mathrm{Mg}^{2+}$. The redox potential for each spinel oxide was determined as the midpoint between the onset potentials obtained using the cathodic and anodic currents. Therefore, the estimated redox potential of $\mathrm{MgMn}_{2} \mathrm{O}_{4}$ was $\sim 2.3 \mathrm{~V} v s . \mathrm{Mg} / \mathrm{Mg}^{2+}$. In contrast, a broad cathodic peak corresponding to the insertion of $\mathrm{Mg}^{2+}$ ions into spinel $\mathrm{MgFe}_{2} \mathrm{O}_{4}$ was observed at a potential lower than $2.3 \mathrm{~V}$ vs. $\mathrm{Mg} /$ $\mathrm{Mg}^{2+}$, and the cathodic peak at $\sim 1.2 \mathrm{~V} v s . \mathrm{Mg} / \mathrm{Mg}^{2+}$ was ascribed to the reduction of TFSA $^{-}$ions (Fig. 3b). The anodic peak observed at $\sim 2.5 \mathrm{~V} v s$. $\mathrm{Mg} / \mathrm{Mg}^{2+}$ during the anodic scan was ascribed to the extraction of $\mathrm{Mg}^{2+}$ ions from rocksalt $\mathrm{Mg}_{2} \mathrm{Fe}_{2} \mathrm{O}_{4}$. The redox potential of $\mathrm{MgFe}_{2} \mathrm{O}_{4}$ was determined to be $\sim 2.1 \mathrm{~V} v s$. $\mathrm{Mg} / \mathrm{Mg}^{2+}$. Conversely, $\mathrm{MgCO}_{2} \mathrm{O}_{4}$ presented the highest redox potential of $\sim 2.4 \mathrm{~V} v s . \mathrm{Mg} / \mathrm{Mg}^{2+}$ among all the spinel oxides, and the distinct redox peaks corresponding to the $\mathrm{Co}^{2+} / \mathrm{Co}^{3+}$ valence change were observed at $\sim 1.6$ and $\sim 3.2 \mathrm{~V} v s . \mathrm{Mg} / \mathrm{Mg}^{2+}$ (Fig. 3c).

The oxidation potentials $\left(E_{\mathrm{ox}}\right)$ of the electrolyte were determined to be $3.05,3.33$, and $3.20 \mathrm{~V}$ vs. $\mathrm{Mg} / \mathrm{Mg}^{2+}$ for $\mathrm{MgMn}_{2} \mathrm{O}_{4}$, $\mathrm{MgFe}_{2} \mathrm{O}_{4}$, and $\mathrm{MgCO}_{2} \mathrm{O}_{4}$ spinel oxides, respectively, based on the potentials at a current density of $0.5 \mathrm{~mA} \mathrm{~g}^{-1}$ during the cathodic sweep (Fig. 3a-c). The divalent transition metal ions in the corresponding rocksalt oxides also oxidized at these $E_{\text {ox }}$ values, resulting in residual rocksalt phases. These $E_{\text {ox }}$ values were lower than $3.8 \mathrm{~V} v$ s. $\mathrm{Mg} / \mathrm{Mg}^{2+}$, which was the potential of the $\mathrm{Al}$ current collector in the absence of spinel oxides, suggesting that spinel oxides exhibited catalytic activity for oxidative electrolyte decomposition.

Therefore, next, the potential scan was initially conducted in the anodic direction from the OCP to evaluate the effect of the spinel oxides on oxidative electrolyte decomposition at the same scan rate of $25 \mu \mathrm{V} \mathrm{s}^{-1}$ (Fig. 3d-f). For $\mathrm{MgMn}_{2} \mathrm{O}_{4}$, the anodic current corresponding to oxidative electrolyte decomposition increased at potentials higher than $3.05 \mathrm{~V} v s . \mathrm{Mg} / \mathrm{Mg}^{2+}$ (Fig. 3d). The small cathodic current observed at a potential lower than $3 \mathrm{~V} v s . \mathrm{Mg} / \mathrm{Mg}^{2+}$ (inset of Fig. 3d) was related to the reduction of $\mathrm{Mn}^{4+}$ ions at higher potentials during electrolyte decomposition. ${ }^{14}$ However, no peaks ascribed to the $\mathrm{Mn}^{2+} / \mathrm{Mn}^{3+}$ redox reaction were observed even at potentials lower than $2 \mathrm{~V}$ 
vs. $\mathrm{Mg} / \mathrm{Mg}^{2+}$, suggesting that electrolyte decomposition and/or decomposition products hindered the redox reaction. For $\mathrm{MgFe}_{2} \mathrm{O}_{4}$, electrolyte decomposition was significantly suppressed, and oxidative electrolyte decomposition occurred at potentials higher than $3.59 \mathrm{~V}$ vs. $\mathrm{Mg} / \mathrm{Mg}^{2+}$ (Fig. 3e). The $\mathrm{Fe}^{2+} /$ $\mathrm{Fe}^{3+}$ redox reaction obviously occurred, indicating that $\mathrm{MgFe}_{2} \mathrm{O}_{4}$ was not significantly affected by oxidative electrolyte decomposition. For $\mathrm{MgCo}_{2} \mathrm{O}_{4}$, oxidative electrolyte decomposition occurred at potentials higher than $3.27 \mathrm{~V}$ vs. $\mathrm{Mg} / \mathrm{Mg}^{2+}$ (Fig. 3f). In contrast to $\mathrm{MgMn}_{2} \mathrm{O}_{4}$, for $\mathrm{MgCo}_{2} \mathrm{O}_{4}$, no cathodic current was observed at $\sim 3 \mathrm{~V}$ vs. $\mathrm{Mg} / \mathrm{Mg}^{2+}$ during the cathodic scan, indicating that no $\mathrm{Co}^{4+}$ ions were formed. Similar to the cyclic voltammogram starting with a cathodic scan (Fig. 3c), the cyclic voltammogram starting with an anodic scan (Fig. $3 \mathrm{f}$ ) presented a cathodic current at a potential lower than $\sim 2.5 \mathrm{~V}$ vs. $\mathrm{Mg} / \mathrm{Mg}^{2+}$. However, the cathodic peak top was observed at a higher potential of $\sim 1.7 \mathrm{~V} v s . \mathrm{Mg} / \mathrm{Mg}^{2+}$ with a lower cathodic current in Fig. 3f compared to the cathodic peak top at $\sim 1.6 \mathrm{~V} v s . \mathrm{Mg} / \mathrm{Mg}^{2+}$ in Fig. 3c, suggesting that the electrolyte decomposition caused the passivation of the active materials and a decrease in the amount of $\mathrm{MgCo}_{2} \mathrm{O}_{4}$ participating in the reaction.

\section{Band diagrams of spinel oxides}

Before proposing a catalytic mechanism that can describe the dependence of oxidative electrolyte decomposition on the type of transition metal ions in the spinel oxides, the electronic states of the spinel oxides were determined using density functional theory (DFT) calculations. The density of states contour plots for the $\mathrm{MgMn}_{2} \mathrm{O}_{4}, \mathrm{MgFe}_{2} \mathrm{O}_{4}$, and $\mathrm{MgCo}_{2} \mathrm{O}_{4}$ slab models are presented in Fig. 4. The slab facet of the (100) surface with the lowest surface energy was selected for $\mathrm{MgMn}_{2} \mathrm{O}_{4}$ and $\mathrm{MgFe}_{2} \mathrm{O}_{4}$ (Table $\mathrm{S} 1 \dagger$ ). Owing to similarity, for $\mathrm{MgCo}_{2} \mathrm{O}_{4}$, the (100) surface, which is close to the most stable, was used instead of the (110) surface with the lowest surface energy. The slab models were constructed by stacking two unit cells to obtain more reliable results, where the slab thickness (>15 $\AA$ ) is sufficiently larger than former studies on spinel-type $\operatorname{LiMn}_{2} \mathrm{O}_{4}(\sim 8 \AA) .{ }^{41,42}$

The conduction band minima (CBMs), which were related to the reduction potentials of $\mathrm{MgM}_{2} \mathrm{O}_{4}(\mathrm{M}=\mathrm{Mn}, \mathrm{Fe}$, and Co) spinel oxides, were associated with the reduction of $\mathrm{M}^{3+}$ to $\mathrm{M}^{2+}$ upon receiving electrons. In contrast, the VBMs, which were related to the oxidation potentials of the spinel oxides, were associated with the $\mathrm{M}^{3+} / \mathrm{M}^{4+}$ oxidation reactions. The narrower the bandgap between the CBM and the VBM, the higher the electrical conductivity of the spinel oxide. Ultraviolet-visible spectroscopy revealed that the generalized gradient approximation (GGA)-calculated band gaps were comparable, yet smaller than the experimental values (Fig. S3†).43,44

Based on the DFT calculations (Fig. 4), we drew schematic band diagrams against the vacuum level for the $\mathrm{MgMn}_{2} \mathrm{O}_{4}$, $\mathrm{MgFe}_{2} \mathrm{O}_{4}$, and $\mathrm{MgCo}_{2} \mathrm{O}_{4}$ spinel oxides (Fig. 5). ${ }^{45}$ The VBMs of the spinel oxides were determined using the values at the center of the slab models. The CBMs of the spinel oxides decreased as follows: $\mathrm{MgFe}_{2} \mathrm{O}_{4}>\mathrm{MgMn}_{2} \mathrm{O}_{4}>\mathrm{MgCo}_{2} \mathrm{O}_{4}$, and these results were in agreement with the inverse trend in reduction
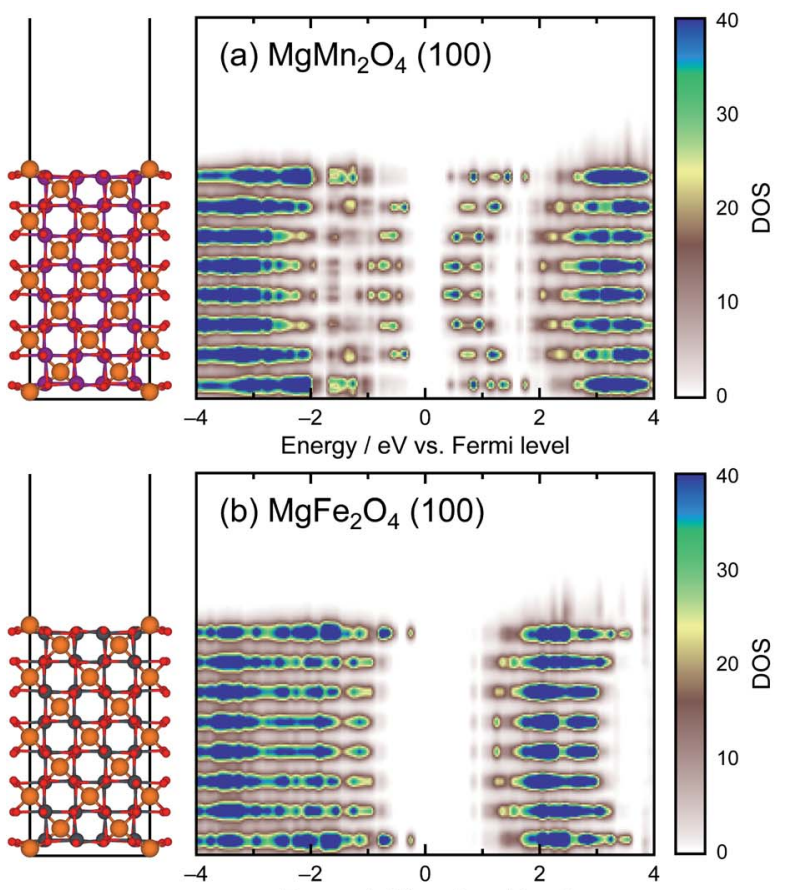

Energy / eV vs. Fermi level

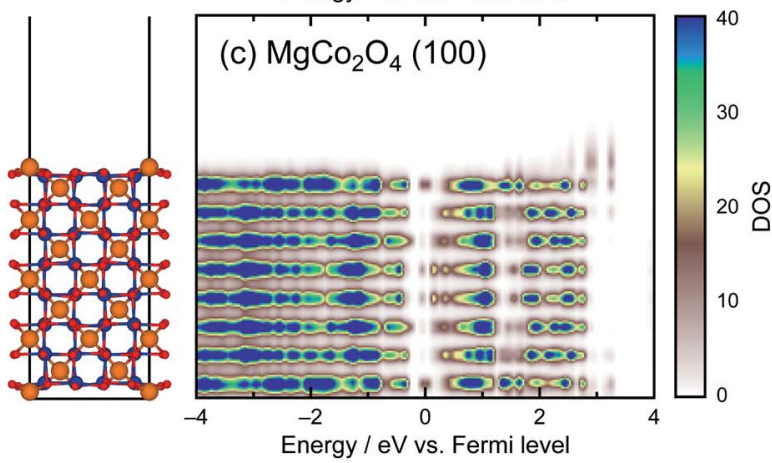

Fig. 4 Density of states (DOS) of the slab models of (a) $\mathrm{MgMn}_{2} \mathrm{O}_{4}$, (b) $\mathrm{MgFe}_{2} \mathrm{O}_{4}$, and (c) $\mathrm{MgCO}_{2} \mathrm{O}_{4}$ spinel oxides as a function of the energy level in the $z$-axis direction.

potentials: $\mathrm{MgFe}_{2} \mathrm{O}_{4}\left(2.1 \mathrm{~V}\right.$ vs. $\left.\mathrm{Mg} / \mathrm{Mg}^{2+}\right)<\mathrm{MgMn}_{2} \mathrm{O}_{4}(2.3 \mathrm{~V}$ vs. $\left.\mathrm{Mg} / \mathrm{Mg}^{2+}\right)<\mathrm{MgCo}_{2} \mathrm{O}_{4}\left(2.4 \mathrm{~V}\right.$ vs. $\left.\mathrm{Mg} / \mathrm{Mg}^{2+}\right)$ obtained from the cyclic voltammograms in Fig. 3a-c. In addition, because the spinel oxides did not undergo reduction upon immersion in the electrolyte, it was suggested that the HOMO of the electrolyte was lower than the CBMs of the spinel oxides. The specific position of the HOMO of the electrolyte is discussed in the following section.

\section{Catalytic mechanism of oxidative electrolyte decomposition}

The schematic of the catalytic mechanism of oxidative electrolytic decomposition is illustrated in Fig. 6. The experimentally demonstrated dependence of the $E_{\text {ox }}$ value of the electrolyte on the spinel oxides suggested that the direct charge transfer from the electrolyte to the electrode was slow. However, charge transfer through the temporary oxidation of the spinel oxides was promoted. Specifically, each spinel oxide was oxidized when the electronic energy of the electrode connected to the 


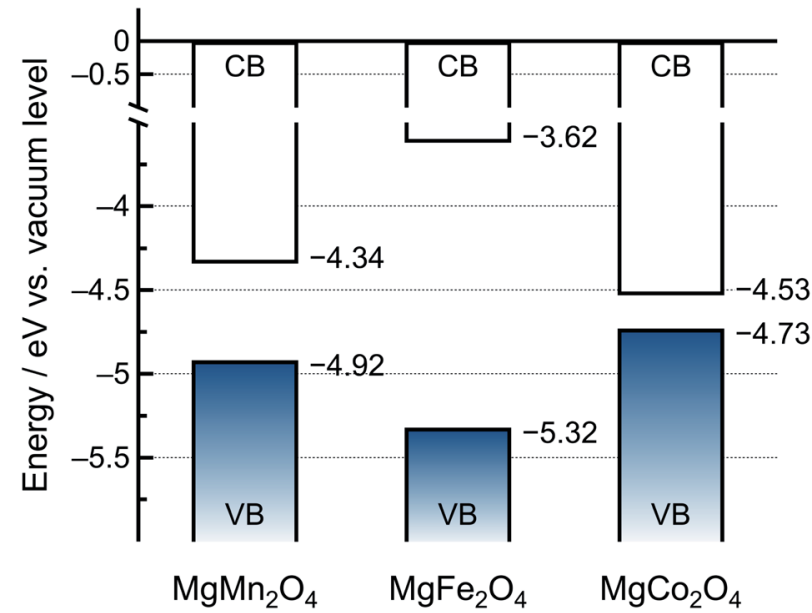

Fig. 5 Schematic band diagram of the slab models of $\mathrm{MgMn}_{2} \mathrm{O}_{4}$, $\mathrm{MgFe}_{2} \mathrm{O}_{4}$, and $\mathrm{MgCO}_{2} \mathrm{O}_{4}$ vs. the vacuum level (CB: conduction band, $\mathrm{VB}$ : valence band).

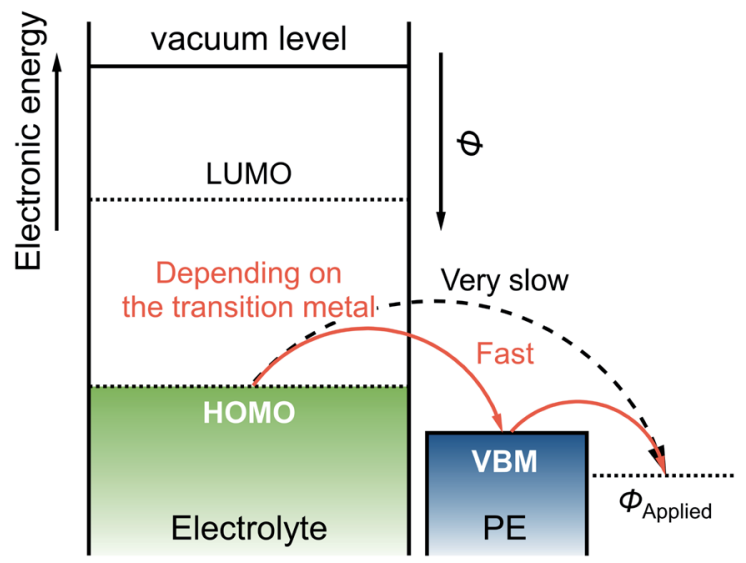

Fig. 6 Schematic energy level diagram of the electrolyte and positive electrode (PE) used to analyze oxidative electrolyte decomposition (HOMO: highest occupied molecular orbital, LUMO: lowest unoccupied molecular orbital, VBM: valence band maximum). Typically, if the electrolyte presents sufficiently high anodic stability, $\mathrm{Mg}^{2+}$ is extracted from spinel oxides for charge compensation during charging. Conversely, if the HOMO of the electrolyte is higher than the VBM of the cathode, the electrolyte is expected to be decomposed instead of undergoing $\mathrm{Mg}^{2+}$ extraction.

potentiostat became lower or the applied potential became higher than the VBM of the spinel oxide. The electron transfer from the electrolyte to the temporarily oxidized spinel oxides was immediately followed by charge compensation. Consequently, oxidative electrolyte decomposition proceeded based on the position of the VBM; the lower the VBM, the higher the $E_{\text {ox }}$ value of the electrolyte. According to the DFT calculations, the VBMs of the spinel oxides decrease as follows $\mathrm{MgCo}_{2} \mathrm{O}_{4}>$ $\mathrm{MgMn}_{2} \mathrm{O}_{4}>\mathrm{MgFe}_{2} \mathrm{O}_{4}$ (Fig. 5), suggesting that $\mathrm{MgFe}_{2} \mathrm{O}_{4}$ exhibited the highest $E_{\mathrm{ox}}$ value. The experimental results confirmed that $\mathrm{MgFe}_{2} \mathrm{O}_{4}$ presented the highest $E_{\text {ox }}$ value ( $3.59 \mathrm{~V} v s . \mathrm{Mg} /$ $\mathrm{Mg}^{2+}$ ) among all the spinel oxides in this study (Fig. 3). However, the experimentally determined $E_{\text {ox }}$ value of the electrolyte on $\mathrm{MgMn}_{2} \mathrm{O}_{4}\left(3.05 \mathrm{~V} v\right.$ s. $\left.\mathrm{Mg} / \mathrm{Mg}^{2+}\right)$ was lower than that on
$\mathrm{MgCo}_{2} \mathrm{O}_{4}\left(3.27 \mathrm{~V}\right.$ vs. $\left.\mathrm{Mg} / \mathrm{Mg}^{2+}\right)$, which contradicted the calculation results. The reason for this is explained below.

In addition to the charge transfer from the electrolyte to the spinel oxides, $\mathrm{Mg}^{2+}$ extraction can promote the neutralization of the oxidized spinel oxides. Owing to the strong electrostatic attraction between $\mathrm{Mg}^{2+}$ and $\mathrm{O}^{2-}$ ions, the extraction of $\mathrm{Mg}^{2+}$ ions from the spinel oxide except for chromate and manganate was hindered..$^{14} \mathrm{~A}$ small cathodic current was observed at $3 \mathrm{~V} v s$. $\mathrm{Mg} / \mathrm{Mg}^{2+}$ only for the $\mathrm{MgMn}_{2} \mathrm{O}_{4}$ spinel oxide (Fig. 3d); however, the main reaction at higher potentials was oxidative electrolyte decomposition. Furthermore, we also confirmed that a small $\mathrm{Mn}^{3+} / \mathrm{Mn}^{4+}$ valence change occurred, as shown in Fig. S4. $\dagger$ Therefore, we hypothesized that the HOMO of the electrolyte was located just below the VBM of $\mathrm{MgMn}_{2} \mathrm{O}_{4}$. The extraction of $\mathrm{Mg}^{2+}$ ions from $\mathrm{MgMn}_{2} \mathrm{O}_{4}$ occurred when the electronic energy of the electrode became lower than the VBM upon charging. If the electronic energy of the electrode became lower than the HOMO of the electrolyte, electron transfer from the electrolyte occurred. Unlike $\mathrm{MgMn}_{2} \mathrm{O}_{4}, \mathrm{MgCo}_{2} \mathrm{O}_{4}$ did not undergo oxidation when the electronic energy of the electrode was intermediate between the VBM of the spinel oxide and the HOMO of the electrolyte because of the strong electrostatic attraction between $\mathrm{Mg}^{2+}$ and $\mathrm{O}^{2-}$ ions. Therefore, the $E_{\text {ox }}$ value of $\mathrm{MgMn}_{2} \mathrm{O}_{4}$ was lower than that of $\mathrm{MgCo}_{2} \mathrm{O}_{4}$. Consequently, the $E_{\mathrm{ox}}$ values of the electrolyte correlated with the positions of the VBMs of the positive electrode active materials unless the HOMO level of the electrolyte was low.

The overpotential and kinetics of oxidative electrolyte decomposition depended on the type of transition metal ions in the spinel oxides. In Fig. 3, the slopes of the anodic currents accompanying oxidative electrolyte decomposition increased in the same order as the $E_{\text {ox }}$ values: $\mathrm{MgMn}_{2} \mathrm{O}_{4}<\mathrm{MgCo}_{2} \mathrm{O}_{4}<$ $\mathrm{MgFe}_{2} \mathrm{O}_{4}$. The linear correlation between the potential and logarithmic current density determined using the cyclic voltammograms in Fig. 3 is presented in Fig. 7. The Tafel slopes of $\mathrm{MgMn}_{2} \mathrm{O}_{4}, \mathrm{MgCo}_{2} \mathrm{O}_{4}$, and $\mathrm{MgFe}_{2} \mathrm{O}_{4}$ spinel oxides were 439, 377,

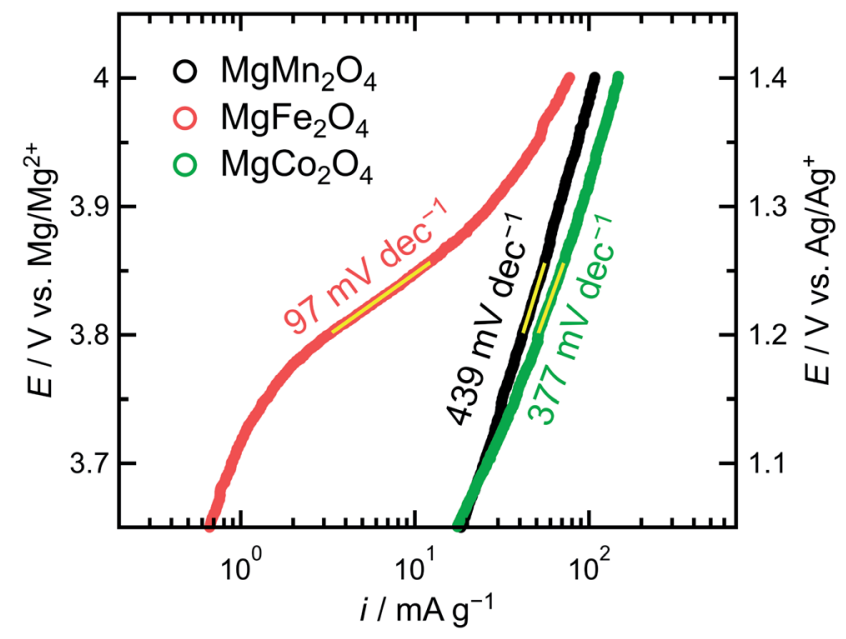

Fig. 7 Tafel plots of the $\mathrm{MgMn}_{2} \mathrm{O}_{4}, \mathrm{MgFe}_{2} \mathrm{O}_{4}$, and $\mathrm{MgCO}_{2} \mathrm{O}_{4}$ spinel oxides. The Tafel slopes were determined in the potential range of $3.80-3.86 \mathrm{~V}$ vs. $\mathrm{Mg} / \mathrm{Mg}^{2+}$. 
and $97 \mathrm{mV} \mathrm{dec}{ }^{-1}$, respectively (note that the order of the Tafel slopes is the opposite of the order of the corresponding slopes of the voltammograms). According to the Butler-Volmer equation, when charge transfer is the rate-limiting step, the current density increases exponentially with increasing polarization. In this case, the catalyst with the lowest overpotential should exhibit the largest current density at the same potential. However, the experimental data contradicted the electrochemical reaction given by the Butler-Volmer equation. Therefore, oxidative electrolytic decomposition was not rate-limited by charge transfer, and the overpotential and current slope should be evaluated separately when discussing catalytic activity.

\section{Experimental}

\section{Synthesis}

Nanocrystalline $\mathrm{MgM}_{2} \mathrm{O}_{4}(\mathrm{M}=\mathrm{Mn}, \mathrm{Fe}$, and $\mathrm{Co})$ powders were synthesized using an inverse co-precipitation method. ${ }^{46}$ $\mathrm{Mg}\left(\mathrm{NO}_{3}\right)_{2} \cdot 6 \mathrm{H}_{2} \mathrm{O}(8 \mathrm{mmol})$ and $\mathrm{Mn}\left(\mathrm{NO}_{3}\right)_{2} \cdot 6 \mathrm{H}_{2} \mathrm{O}, \mathrm{Fe}\left(\mathrm{NO}_{3}\right)_{3}{ }^{-}$ - $9 \mathrm{H}_{2} \mathrm{O}$, or $\mathrm{Co}\left(\mathrm{NO}_{3}\right)_{2} \cdot 6 \mathrm{H}_{2} \mathrm{O}(16 \mathrm{mmol})$ were dissolved in $100 \mathrm{~mL}$ of deionized water under stirring (500 rpm) at room temperature. $\mathrm{Na}_{2} \mathrm{CO}_{3}(70 \mathrm{mmol})$ was dissolved in $200 \mathrm{~mL}$ of deionized water under stirring $(500 \mathrm{rpm})$ at $80{ }^{\circ} \mathrm{C}$. Thereafter, the mixed metallic nitrate salt aqueous solution was added to a sodium carbonate aqueous solution using a peristaltic pump (ATTO, SJ$1211 \mathrm{II}-\mathrm{H}$ ) at a rate of 1-2 $\mathrm{mL} \mathrm{min}^{-1}$ under vigorous stirring (700 $\mathrm{rpm})$. Because of the precipitation reaction, the clear solution gradually turned into light brown (Mn), dark brown (Fe), or navy (Co) suspensions. The suspensions were stirred for $30 \mathrm{~min}$ without heating them, followed by filtration under vacuum. The filtered precipitates (precursors) were rinsed with deionized water at $80{ }^{\circ} \mathrm{C}$ to remove the residual Na-containing byproducts. Thereafter, the $\mathrm{pH}$ of the filtrate, which was measured using $\mathrm{pH}$ test paper, was adjusted to $\sim 7$, followed by drying the precursors in air at $80{ }^{\circ} \mathrm{C}$ for $24 \mathrm{~h}$. Subsequently, the agglomerated precursors were pulverized via ball milling at $300 \mathrm{rpm}$ for $8 \times 15 \mathrm{~min}$ in $5 \mathrm{~min}$ intervals, followed by calcination at $500{ }^{\circ} \mathrm{C}$ for $12 \mathrm{~h}$ at a heating rate of $10{ }^{\circ} \mathrm{C} \mathrm{min}{ }^{-1}$.

\section{Electrochemical tests}

The electrochemical performance of the $\mathrm{MgM}_{2} \mathrm{O}_{4}(\mathrm{M}=\mathrm{Mn}, \mathrm{Fe}$, and $\mathrm{Co}$ ) spinel oxides was evaluated using a three-electrode cell. We used a composite electrode, a $\mathrm{Mg}$ ribbon (99.9\%) polished with sandpaper (\#150), and a $\mathrm{Ag} / \mathrm{Ag}^{+}$electrode as the WE, CE, and $\mathrm{RE}$, respectively. The $\mathrm{Ag} / \mathrm{Ag}^{+}$electrode was fabricated by immersing a $\mathrm{Ag}$ wire into a glass tube containing a porous vycor glass and $450 \mu \mathrm{L}$ of triethyleneglycol dimethyl ether (G3) solution containing $0.01 \mathrm{M} \mathrm{AgNO}_{3}$ and $0.10 \mathrm{M} \mathrm{Mg}(\mathrm{TFSA})_{2}$. The composite electrode was prepared from a slurry comprising a mixture of the calcined nanocrystalline $\mathrm{MgM}_{2} \mathrm{O}_{4}$ powder (active material), SP (conductive agent), and PVdF (binder) with a mass ratio of $8: 1: 1$ dissolved in $N$-methyl-2-pyrrolidone (NMP). After the addition of $600 \mu \mathrm{L}$ of NMP, the slurry was mixed using a rotation-revolution mixer (Thinky, ARE-310) at $2000 \mathrm{rpm}$ for $20 \mathrm{~min}$, spread on an Al plate (current collector), and dried under vacuum at $80{ }^{\circ} \mathrm{C}$ overnight.
The $[\mathrm{Mg}(\mathrm{G} 4)][\mathrm{TFSA}]_{2} /[$ Pyr1,3][TFSA $]$ electrolyte was prepared according to the method described in a previous paper. ${ }^{25} \mathrm{Mg}$ $[\text { TFSA }]_{2}(5 \mathrm{mmol})$ and $\mathrm{G} 4(5 \mathrm{mmol})$ were added to a $10 \mathrm{~mL}$ volumetric flask, and the flask was filled to the mark with [Pyr1,3][TFSA]. The mixture was vigorously stirred at $100{ }^{\circ} \mathrm{C}$ overnight. The G3, G4, and [Pyr1,3][TFSA] solutions were dried over molecular sieves $(3 \AA)$, heated at $250{ }^{\circ} \mathrm{C}$ for $3 \mathrm{~h}$ and then again heated at $300{ }^{\circ} \mathrm{C}$ for $4.5 \mathrm{~h}$ under vacuum before use. The three-electrode cell was fabricated in an Ar-filled glove box with a dew point lower than $-80{ }^{\circ} \mathrm{C}$.

All the electrochemical measurements were performed at $100{ }^{\circ} \mathrm{C}$ using a three-electrode cell set in an $\mathrm{Al}$ block placed on a hot plate to maintain a constant temperature. The cyclic voltammograms of $\mathrm{MgM}_{2} \mathrm{O}_{4}$ were obtained using a potentiostat (Biologic, VSP-300) at a scan rate of $25 \mu \mathrm{V} \mathrm{s}^{-1}$. The lowest cut-off potential was set at $0.8 \mathrm{~V} v s . \mathrm{Mg} / \mathrm{Mg}^{2+}$ because the reductive decomposition of the TFSA-based electrolyte occurred at lower potentials.

\section{Material characterization}

The valence state of transition metal ions in spinel oxides before and after chronocoulometry under potentiostatic control of $4 \mathrm{~V}$ vs. $\mathrm{Mg} / \mathrm{Mg}^{2+}$ was investigated by X-ray absorption spectroscopy (XAS) at the BL14B2 beamline of Spring-8. The samples were prepared by mixing active materials with boron nitride (diluent) and pressing them into pellets.

The spinel-type $\mathrm{MgM}_{2} \mathrm{O}_{4}(\mathrm{M}=\mathrm{Mn}$, Fe, and Co) compounds were packed in a Lindeman glass capillary with an outer diameter of $0.5 \mathrm{~mm}$ and a glass thickness of $0.01 \mathrm{~mm}$ and were subjected to synchrotron X-ray diffraction (SXRD) analysis at the BL02B2 beamline of SPring-8. The X-ray wavelength was 0.4200 A for $\mathrm{MgM}_{2} \mathrm{O}_{4}$ powders and $0.5000 \AA$ for the composite electrode as prepared and after chronocoulometry, which were calibrated using a $\mathrm{CeO}_{2}$ standard. The crystal structures were drawn using the VESTA software, ${ }^{\mathbf{4 7}}$ and Rietveld refinement was performed using the SXRD data and the RIETAN-FP software (Table S2, and Fig. $\mathrm{S} 5 \dagger){ }^{48}$

\section{Computational details}

First-principles calculations based on the DFT data were performed to optimize the crystal structures of the bulk and surface models of spinel-type $\mathrm{MgM}_{2} \mathrm{O}_{4}(\mathrm{M}=\mathrm{Mn}, \mathrm{Fe}$, and Co). We used the Vienna $a b$ initio simulation package (VASP) ${ }^{49}$ with the modified Perdew-Burke-Ernzerhof GGA for solids (PBEsolGGA) ${ }^{50,51}$ and the projector-augmented wave (PAW) method. ${ }^{52}$ On-site Coulomb correction (DFT $+U$ ) was performed for the localized electronic states, and the $U$ values for the $\mathrm{Mn}, \mathrm{Fe}$, and Co $3 \mathrm{~d}$ states were set to $3.9,5.3$, and $3.32 \mathrm{eV}$, respectively, using data reported in the literature. ${ }^{53}$ First, structural calculations were performed for the bulk structures of the $\mathrm{MgM}_{2} \mathrm{O}_{4}(\mathrm{M}=$ $\mathrm{Mn}, \mathrm{Fe}$, and Co) spinel oxides using the DFT $+U$ approach under the assumption that the $\mathrm{Mg}$ and $\mathrm{M}$ ions occupied tetrahedral and octahedral sites, respectively. This assumption was based on the symmetry requirements for surface electronic structure calculations, although we reported that $\mathrm{Mg}$ and $\mathrm{M}$ exchange occurred in the $\mathrm{MgM}_{2} \mathrm{O}_{4}$ compounds. ${ }^{46}$ A conventional 
$\mathrm{Mg}_{8} \mathrm{M}_{16} \mathrm{O}_{32}(F d \overline{3} m)$ face-centered unit cell model and $3 \times 3 \times 3$ $k$-point grids were used. After determining the cubic lattice parameters of the spinel oxides, the surface structures were computed using the slab technique, wherein a set of infinite layers separated by vacuum layers were repeated periodically along the surface normal. The low-index facets of the (001), (011), and (111) surfaces consisting of charge-balanced stoichiometric slabs were modeled in this study using data from the literature. ${ }^{42}$ The slab thicknesses for the (001), (011), and (111) surfaces were $\sim 16, \sim 12$, and $\sim 11 \AA$, respectively, and that of the vacuum layers was set to $\sim 30 \AA$. In addition, the slabs were constructed such that their sides were symmetrically equivalent and could be mapped into each other via an inversion or mirror type of symmetry operation in the middle of the slabs. The $k$ point grids for the surface models were set to be $3 \times 3 \times 1$.

\section{Conclusions}

In summary, we demonstrated the oxidative decomposition mechanism of a TFSA-based electrolyte. The charge transfer from the electrolyte to the electrode was slow and was promoted or catalyzed by the temporary oxidation of spinel oxides. The $E_{\mathrm{ox}}$ values of the electrolyte depended on the VBMs of spinel oxides; the lower the VBM, the higher the $E_{\text {ox }}$ value of the electrolyte. DFT calculations demonstrated that the VBM of $\mathrm{MgFe}_{2} \mathrm{O}_{4}$ was the lowest among all the spinel oxides, which was in agreement with the highest $E_{\text {ox }}$ value of the electrolyte on $\mathrm{MgFe}_{2} \mathrm{O}_{4}$ (i.e., the largest overpotential for oxidative electrolyte decomposition). Therefore, the addition of ions with lower VBMs, such as Fe ions, can suppress oxidative electrolyte decomposition, improving the stability of MRBs.

\section{Conflicts of interest}

There are no conflicts to declare.

\section{Acknowledgements}

The authors would like to thank Professor Kiyoshi Kanamura (Tokyo Metropolitan University) and Dr Kohei Uosaki (National Institute for Materials Science) for their valuable advice. This study was supported by the Advanced Low Carbon Technology Research and Development Program, Specially Promoted Research for Innovative Next Generation Batteries (ALCASPRING: JPMJAL1301) of the Japan Science and Technology Agency (JST) and the Japan Society for the Promotion of Science (JSPS: 18H05249, 20H05180). This study was also financially supported by a Grant-in-Aid from The University of Tokyo Excellent Young Researcher and the GIMRT Program of the Institute for Materials Research, Tohoku University (Proposal No. 20K0086). XAS and SXRD measurements were conducted at the BL14B2 beamline (Proposal No. 2021B1726) and the BL02B2 beamline (Proposal No. 2020A0583 and 2021B1327) of SPring-8, respectively.

\section{Notes and references}

1 H. D. Yoo, I. Shterenberg, Y. Gofer, G. Gershinsky, N. Pour and D. Aurbach, Energy Environ. Sci., 2013, 6, 2265.

2 P. Canepa, G. Sai Gautam, D. C. Hannah, R. Malik, M. Liu, K. G. Gallagher, K. A. Persson and G. Ceder, Chem. Rev., 2017, 117, 4287-4341.

3 I. Shterenberg, M. Salama, Y. Gofer, E. Levi and D. Aurbach, MRS Bull., 2014, 39, 453-460.

4 D. R. Lide, CRC Handbook of Chemistry and Physics, CRC Press, Boca Raton 2003.

5 M. Matsui, J. Power Sources, 2011, 196, 7048-7055.

6 C. You, X. Wu, X. Yuan, Y. Chen, L. Liu, Y. Zhu, L. Fu, Y. Wu, Y.-G. Guo and T. van Ree, J. Mater. Chem. A, 2020, 8, 2560125625.

7 D. Aurbach, Z. Lu, A. Schechter, Y. Gofer, H. Gizbar, R. Turgeman, Y. Cohen, M. Moshkovich and E. Levi, Nature, 2000, 407, 724-727.

8 K. Taniguchi, Y. Gu, Y. Katsura, T. Yoshino and H. Takagi, Appl. Phys. Express, 2016, 9, 011801.

9 M. Wang, J. Han, W. Liu, M. Kamiko and S. Yagi, J. Alloys Compd., 2021, 883, 160822.

10 Y. Orikasa, T. Masese, Y. Koyama, T. Mori, M. Hattori, K. Yamamoto, T. Okado, Z.-D. Huang, T. Minato, C. Tassel, J. Kim, Y. Kobayashi, T. Abe, H. Kageyama and Y. Uchimoto, Sci. Rep., 2015, 4, 5622.

11 Y. Nuli, Y. Zheng, Y. Wang, J. Yang and J. Wang, J. Mater. Chem., 2011, 21, 12437-12443.

12 T. Hatakeyama, H. Li, N. L. Okamoto, K. Shimokawa, T. Kawaguchi, H. Tanimura, S. Imashuku, M. Fichtner and

T. Ichitsubo, Chem. Mater., 2021, 33, 6983-6996.

13 T. Hatakeyama, N. L. Okamoto, K. Shimokawa, H. Li, A. Nakao, Y. Uchimoto, H. Tanimura, T. Kawaguchi and T. Ichitsubo, Phys. Chem. Chem. Phys., 2019, 21, 2374923757.

14 S. Okamoto, T. Ichitsubo, T. Kawaguchi, Y. Kumagai, F. Oba, S. Yagi, K. Shimokawa, N. Goto, T. Doi and E. Matsubara, Adv. Sci., 2015, 2, 1500072.

15 K. Shimokawa, T. Atsumi, M. Harada, R. E. Ward, M. Nakayama, Y. Kumagai, F. Oba, N. L. Okamoto, K. Kanamura and T. Ichitsubo, J. Mater. Chem. A, 2019, 7, 12225-12235.

16 X. Sun, P. Bonnick, V. Duffort, M. Liu, Z. Rong, K. A. Persson, G. Ceder and L. F. Nazar, Energy Environ. Sci., 2016, 9, 22732277.

17 S. K. Kolli and A. Van der Ven, Chem. Mater., 2021, 33, 64216432.

18 T. Chen, G. Sai Gautam and P. Canepa, Chem. Mater., 2019, 31, 8087-8099.

19 Z. Rong, R. Malik, P. Canepa, G. Sai Gautam, M. Liu, A. Jain, K. Persson and G. Ceder, Chem. Mater., 2015, 27, 6016-6021. 20 K. Ishii, S. Doi, R. Ise, T. Mandai, Y. Oaki, S. Yagi and H. Imai, J. Alloys Compd., 2020, 816, 152556.

21 K. Shimokawa, T. Atsumi, N. L. Okamoto, T. Kawaguchi, S. Imashuku, K. Wagatsuma, M. Nakayama, K. Kanamura and T. Ichitsubo, Adv. Mater., 2021, 33, 2007539. 
22 Y. Idemoto, N. Kawakami, N. Ishida and N. Kitamura, J. Power Sources, 2020, 455, 227962.

23 Y. Idemoto, M. Ichiyama, N. Ishida and N. Kitamura, J. Power Sources, 2021, 482, 228920.

24 S. Yagi, A. Tanaka, Y. Ichikawa, T. Ichitsubo and E. Matsubara, J. Electrochem. Soc., 2013, 160, C83-C88.

25 T. Mandai, K. Tatesaka, K. Soh, H. Masu, A. Choudhary, Y. Tateyama, R. Ise, H. Imai, T. Takeguchi and K. Kanamura, Phys. Chem. Chem. Phys., 2019, 21, 1210012111.

26 S.-Y. Ha, Y.-W. Lee, S. W. Woo, B. Koo, J.-S. Kim, J. Cho, K. T. Lee and N.-S. Choi, ACS Appl. Mater. Interfaces, 2014, 6, 4063-4073.

27 H. Kuwata, M. Matsui and N. Imanishi, J. Electrochem. Soc., 2017, 164, A3229-A3236.

28 S. J. Kang, H. Kim, S. Hwang, M. Jo, M. Jang, C. Park, S. T. Hong and H. Lee, ACS Appl. Mater. Interfaces, 2019, 11, 517-524.

29 J. Han, S. Yagi and T. Ichitsubo, J. Power Sources, 2019, 435, 226822.

30 S. Yagi, A. Tanaka, T. Ichitsubo and E. Matsubara, ECS Electrochem. Lett., 2012, 1, D11-D14.

31 S. Yagi, A. Tanaka, Y. Ichikawa, T. Ichitsubo and E. Matsubara, Res. Chem. Intermed., 2014, 40, 3-9.

32 O. Mizrahi, N. Amir, E. Pollak, O. Chusid, V. Marks, H. Gottlieb, L. Larush, E. Zinigrad and D. Aurbach, J. Electrochem. Soc., 2008, 155, A103.

33 H. S. Kim, T. S. Arthur, G. D. Allred, J. Zajicek, J. G. Newman, A. E. Rodnyansky, A. G. Oliver, W. C. Boggess and J. Muldoon, Nat. Commun., 2011, 2, 427.

34 Y. Guo, F. Zhang, J. Yang, F. Wang, Y. NuLi and S. Hirano, Energy Environ. Sci., 2012, 5, 9100.

35 R. E. Doe, R. Han, J. Hwang, A. J. Gmitter, I. Shterenberg, H. D. Yoo, N. Pour and D. Aurbach, Chem. Commun., 2014, 50, 243-245.

36 O. Tutusaus, R. Mohtadi, T. S. Arthur, F. Mizuno, E. G. Nelson and Y. V. Sevryugina, Angew. Chem., Int. Ed., 2015, 54, 7900-7904.
37 H. Dong, O. Tutusaus, Y. Liang, Y. Zhang, Z. Lebens-Higgins, W. Yang, R. Mohtadi and Y. Yao, Nat. Energy, 2020, 5, 10431050.

38 T. Mandai, Y. Akita, S. Yagi, M. Egashira, H. Munakata and

K. Kanamura, J. Mater. Chem. A, 2017, 5, 3152-3156.

39 T. Mandai, K. Yoshida, S. Tsuzuki, R. Nozawa, H. Masu, K. Ueno, K. Dokko and M. Watanabe, J. Phys. Chem. B, 2015, 119, 1523-1534.

40 S. Terada, T. Mandai, S. Suzuki, S. Tsuzuki, K. Watanabe, Y. Kamei, K. Ueno, K. Dokko and M. Watanabe, J. Phys. Chem. C, 2016, 120, 1353-1365.

41 A. Karim, S. Fosse and K. A. Persson, Phys. Rev. B: Condens. Matter Mater. Phys., 2013, 87, 075322.

42 M. Nakayama, H. Taki, T. Nakamura, S. Tokuda, R. Jalem and T. Kasuga, J. Phys. Chem. C, 2014, 118, 27245-27251.

43 W. B. Park, S. U. Hong, S. P. Singh, M. Pyo and K.-S. Sohn, ACS Omega, 2016, 1, 483-490.

44 J.-H. Yuan, Q. Chen, L. R. C. Fonseca, M. Xu, K.-H. Xue and X.-S. Miao, J. Phys. Commun., 2018, 2, 105005.

45 M. Nakayama, K. Ishida, K. Watanabe, N. Tanibata, H. Takeda, H. Maeda and T. Kasuga, ACS Omega, 2020, 5, 4083-4089.

46 S. Yagi, Y. Ichikawa, I. Yamada, T. Doi, T. Ichitsubo and E. Matsubara, Jpn. J. Appl. Phys., 2013, 52, 025501.

47 K. Momma and F. Izumi, J. Appl. Crystallogr., 2011, 44, 12721276.

48 F. Izumi and K. Momma, Solid State Phenom., 2007, 130, 1520.

49 G. Kresse and J. Furthmüller, Phys. Rev. B: Condens. Matter Mater. Phys., 1996, 54, 11169-11186.

50 J. P. Perdew, K. Burke and M. Ernzerhof, Phys. Rev. Lett., 1996, 77, 3865-3868.

51 J. P. Perdew, A. Ruzsinszky, G. I. Csonka, O. A. Vydrov, G. E. Scuseria, L. A. Constantin, X. Zhou and K. Burke, Phys. Rev. Lett., 2008, 100, 136406.

52 P. E. Blöchl, Phys. Rev. B: Condens. Matter Mater. Phys., 1994, 50, 17953-17979.

53 A. Jain, S. P. Ong, G. Hautier, W. Chen, W. D. Richards, S. Dacek, S. Cholia, D. Gunter, D. Skinner, G. Ceder and K. A. Persson, APL Mater., 2013, 1, 011002. 